\title{
Adulteration of milk in Pakistan: Are we drinking milk or milk like liquid?
}

\author{
Muhammad Salman Haider Qureshi ${ }^{1 *}$, Ramsha Khan ${ }^{2}$ \\ ${ }^{1}$ Department of Public Health, Khyber Medical University, Peshawar Pakistan \\ ${ }^{2}$ Department of Health Promotion and Public Health, University of West London, United Kingdom
}

Keywords: Adulteration, Milk, Vitamins, Enzymes, Punjab food authority

Accepted on August 13, 2018

Milk is one of the most important constituents of human diet and is not only an excellent natural source of carbohydrates, fats and proteins but also of vitamins, minerals and enzymes [1]. This makes milk an ideal drink for all ages. Milk is known for its nutritious importance and its role in strengthening of bones, teeth, muscles and lowering the risk of osteoporosis, osteoarthritis, ischemic heart disease, depression and cancers [2]. All these benefits of milk can only be obtained if we consume milk in its pure form. However, it has been brought into the notice of concerned authorities that milk which is routinely sold in different parts of Pakistan is unhealthy and many milk sellers have been found to be involved in adulteration of milk [3].

On one hand, if pure milk ensures healthy growth and nourishment then on the other hand, adulterated milk causes morbidity and serious health outcomes [4]. It has been reported that the milk sellers in Pakistan were found to be involved in mixing milk with contaminated water, harmful chemicals, detergent powder, pharmaline and urea [5]. Apart from that it has also been reported that milk is stored and transferred in barrels that are usually used for transportation of chemicals. In this serious crime of adulteration, not only domestic dealers are involved but many notable companies are also engaged [6-8]. According to Punjab Food Authority, only 27 out of 52 samples of milk were found to be adequate for drinking. Another report revealed that 18 out of 25 samples of milk collected from Peshawar, a major city of Pakistan were found unhealthy [9]. A local newspaper revealed that 12 famous milk selling brands were found to be involved in adulteration of milk [10]. Another report provided by government officials stated that out of 200 milk brands, only 2 were found safe for consumption [11].

It is the duty of government to ensure availability of safe and pure milk for its citizens. The Pakistan Council of Scientific Industrial Research and Pakistan Medical Research Council should conduct a collaborative nation-wide screening of all the available milk samples to generalize the results. The concern shown by Supreme Court of Pakistan in this regard is highly admirable however further steps are required to be taken by the honorable court to take effective actions against the mafia that is involved in adulteration of milk. The role of print and electronic media in highlighting this issue is also appreciable. There is a need of a dedicated operational laboratory and research centre with modern equipment and state of art facilities that would be responsible for quality assurance of milk and certification of milk selling companies. In short, an effective inter-departmental collaboration supported by community and backed by district and federal governments is required to tackle this serious public health issue. Otherwise, there is a strong likelihood that adulterated milk might serve as a cause of epidemic of different diseases in near future.

\section{References}

1. American Academy of Pediatrics Committee on Nutrition. The use of whole cow's milk in infancy. Pediatrics. 1992;89:1105-9.

2. Ware MWebberley H. Milk: Health benefits and nutritional information. Medical News Today. 2017.

3. https://www.thenews.com.pk/print/175023-No-right-towork-if-children-cannot-be-given-pure-milk-Justice-Saqib

4. Lateef M, Faraz A, Mustafa MI, et al. Detection of adulterants and chemical composition of milk supplied to canteens of various hospitals in Faisalabad city. Pak. J. Zool. 2009;9:139-42.

5. Faraz A, Lateef M, Mustafa MI, et al. Detection of adulteration, chemical composition and hygienic status of milk supplied to various canteens of educational institutes and public places in Faisalabad. J Animal Plant Sci. 2013 Jan 1;23(1):119-24.

6. Khan BB, Mustafa MI, Abdullah M, et al. Chemical and hygienic quality of milk supplied to canteens of various hospitals in Faisalabad city. Pak. J. Agri. Sci. 1991;28(4):404-7.

7. Mustafa MI, Khan BB, Abdullah M, et al. Chemical and hygienic quality of milk supplied to canteens of various educational institutions in Faisalabad city. Pak J Agri Sci. 1991;28:9-12.

8. Barham GS, Khaskheli M, Soomro AH, et al. Extent of extraneous water and detection of various adulterants in market milk at Mirpurkhas, Pakistan. IOSR Journal of Agriculture and Veterinary Science. 2014;7:83-9.

9. https://www.thenews.com.pk/print/178476-Sale-ofadulterated-milk-goes-on-unchecked

10. Daily Times. Adulteration: A silent killer. 2017.

11. https://www.counselheal.com/articles/30528/20170117/ milk-safety-news-only-2-out-of-200-brands-found-safe-fordrinking-in-pakistan.htm

\section{*Correspondence to:}

Dr. Muhammad Salman Haider Qureshi

Department of Public Health

Khyber Medical University

Peshawar, Pakistan

E-mail: pmc.salmanqureshi@gmail.com 